\title{
Amelioration Of Educational Conditions Through School Management Committees
}

\author{
Muhammad Imran Yousuf, PMAS Arid Agriculture University, Pakistan \\ Muhammad Tayab Alam, Foundation University, Rawalpindi, Pakistan \\ Muhammad Latif Sajjad, School Wing, Gujranwala, Pakistan \\ Muhammad Imran, UIER, Rawalpindi, Pakistan
}

\begin{abstract}
Community participation in planning and managing for increased educational opportunity is necessary. To ensure the involvement of local community, the government of Pakistan experimentally launched a scheme in 1994 by establishing School Management Committees (S.M.CS). The major purpose of the present study was to observe the functions and performance of S.M.Cs in Promoting Education in Pakistan. The government schools of Punjab Province were considered to be the target population. The study sample consisted of SMCs. of eight government higher secondary schools, 34 government high schools and 34 government elementary schools the Punjab. A survey-type study questionnaire was used to gather the data which were collected and interpreted by using simple statistical techniques of percentage, mean, standard deviation, and t-test. Tentative conclusions are drawn with regard to observations of head teachers and memebrs of SMCs.
\end{abstract}

Keywords: School Management Committee; Head teacher; Functions; School and Community; School Improvement

\section{INTRODUCTION}

6 ducation is a social process which prepares the younger generation of society for life. It is the means of transmitting the values and accumulated knowledge of a society to its younger generation. It prepares them to face varying situations in life. It is designed to teach them their culture, mold their behavior and prepare and train them to eventually play their role in society (Sarwar, 1984). The same focused system of education is needed in Pakistan for harmony and unity in society (Sarwar et. al., 2010). Schools play an important role in education. The education system is administered at different levels. The lowest, but most important and vital level of administration is school management. Management is the process under taken by one or more individuals to coordinate the activities of the others to achieve results not achievable by an individual acting alone. School management is the cooperative process of using individual and group power of school and community in order to develop socially desirable learning experiences for children and youth (Farooq, 1994). School is a place to promote cooperation and embracing of students as members of the school community. (Yousuf et. al., 2010)

Centralization and decentralization are the two styles of school management/administration. Decisions are relatively made by a few people in a centralized system in both instruction and administration (UNESCO, 1997). Centralization stands for concentration of authority at or near the top of the administrative hierarchy. Decentralization, on the other hand, means devolution of powers from above, implying dispersal of power among a number of subordinate officials or an administrative unit. Decentralization leads to closer citizen-administration contact leading to greater public participation in administration (Shahid, 1998).

Educationists agree that improvement in education is not possible until parents and community are involved in school management affairs. School-based management has been in practice since the 1970s in different parts of the world (Cheung \& Kan, 2009). The educational system of Pakistan needs revolutionary and urgent change and if we want to compete with other regional countries, then this system should be changed soon. In ours, 
there is no character of local community in institutional management. Pakistan's National Education Policy (19982010) emphasized to involve the local community in day-to-day management by each school through a management committee (Govt. of Pakistan, 1998). To provide a remedy for this defect and ensure the involvement of the local community, the government of the Punjab Province (Pakistan) experimentally launched a new scheme in 1994 by establishing School Management Committees (S.M.Cs) (Jamil, 1996). Local individuals were involved in these committees with some authority of purchasing funding and performing other administrative functions of schools.

Community participation in education may take different forms depending on the characteristics of the community. There is a spectrum of "appropriate involvement", according to the capacity of the community, to organize itself. In the terrain of formal schooling, the approach emphasizes community participation through community-based structures, such as school management committees at the local level (Ahmed, 1997; Jamil, 1996),

School Management Committee is a structure of government at the school level that will make it possible for the community to participate and mobilize their human/physical resources for the development of basic education at the local level. The dominant connotation is to shift authority from the district to school level which allows participation, facilitation, mobilization and to promote efficiency (Ahmed, 1997). Such committees are expected to contribute to identifying, planning, implementing and monitoring all educational activities and to raise the community's share of resources in cost sharing projects (Jamil, 1996). The policy provisions in the National Education Policy (1998-2010) indicate that at the village level, the chairman of the School Management Committee, who will be an elected person, will constantly review educational development in the area of his jurisdiction. Governments' major initiative for engendering grassroots community participation in the delivery of public sector basic education has been via the formation of school management committees and parent teacher associations (Khan, 2000).

\title{
OBJECTIVES OF THE STUDY
}

\author{
The objectives of the study were: \\ - $\quad$ to identify the school community interrelationship \\ - $\quad$ to study the supervision and performance of School Management Committees in terms of head teachers and \\ members of SMCs observations \\ - $\quad$ to develop a future strategy for School Management Committees
}

\section{Delimitations}

The study was delimited to:

- $\quad$ government schools of Punjab Province

- $\quad$ SMCs of government elementary, high and higher secondary schools

\section{METHODOLOGY}

\section{Population}

The population of this study consisted of all the SMCs of government schools in Punjab Province. The target population consisted of schools in Punjab Province and was further divided into three levels of schooling; i.e., elementary, high and higher secondary schools.

\section{Sample}

A sample of 76 government schools (15\% of target population) was selected by using a random sampling technique. The sample schools were confined to the selected districts in Punjab Province. The government boys schools in rural areas, as well as schools in some urban areas, were selected to make the sample as representative as possible. The sample consisted of 76 schools, including 34 government elementary schools, 34 government high schools and eight government higher secondary schools. 


\section{Instrument}

To collect the information from different sources, two questionnaires were constructed. These were meant for the headmasters and members of SMCs. The questionnaires dealt with such subjects as the school community relationship, establishment of SMCs, the selection of members, administrative decisions, discipline, provision of facilities, results, enrolment and dropout rates, school welfare, promotion of education, and cooperation of SMC members with a head teacher.

\section{Data Analysis}

Data collected through the above-mentioned instrument were tabulated and interpreted category-wise. To analyze the data, mean, standard deviation and t-tests were applied.

\section{RESULTS}

Table 1: Supervision of School Management Committees' Functions

\begin{tabular}{|l|c|c|c|c|c|}
\hline \multicolumn{1}{|c|}{ Items } & \multicolumn{2}{c|}{ Head teacher } & \multicolumn{2}{c|}{ Members } & \multirow{2}{*}{ t value } \\
\cline { 2 - 5 } & Mean & SD & Mean & SD & \\
\hline Members of SMC are selected under supervision. & 2.61 & 0.63 & 2.52 & 0.55 & 0.96 \\
\hline Select members from the representatives of local community. & 2.63 & 0.56 & 2.37 & 0.69 & $2.46^{*}$ \\
\hline Meetings of SMC are held regularly as per schedule & 2.47 & 0.60 & 2.53 & 0.60 & 0.68 \\
\hline All the members of SMC attend these meeting regularly. & 2.01 & 0.72 & 2.51 & 0.55 & $4.68^{*}$ \\
\hline The members of SMC are found passive. & 1.45 & 0.78 & 1.81 & 0.75 & $2.89^{*}$ \\
\hline The record of proceedings of all the meetings is maintained. & 2.6 & 0.62 & 2.48 & 0.53 & 1.28 \\
\hline Pre planning with the cooperation of SMC & 2.43 & 0.64 & 2.45 & 0.66 & 0.25 \\
\hline Discussion is involved about school management. & 2.28 & 0.76 & 2.8 & 0.57 & $4.73^{*}$ \\
\hline A constructive change in school management is felt & 2.52 & 0.81 & 2.09 & 0.79 & 0.20 \\
\hline The members create hindrance in administrative decisions. & 1.96 & 0.91 & 2.36 & 0.67 & $2.87^{*}$ \\
\hline The school discipline has been effected by SMC. & 1.95 & 0.94 & 2.43 & 0.64 & $3.65^{*}$ \\
\hline Have to face problems by the establishment of SMCs. & 1.88 & 0.32 & 2.37 & 0.63 & $3.84^{*}$ \\
\hline
\end{tabular}

Corresponding $\mathrm{t}=1.96$ with $\mathrm{df}=148$, at 0.05 level

Table 1 indicates the extent to which supervision of SMCs functions were observed by head teachers and members of SMCs. Both groups have similar type of observations about selection of members under proper supervision and approval from authorities, observing the schedules of meetings, maintaining the meeting records, preplanning in a cooperative manner, and feeling a constructive change in school management after establishment of SMCs. There was, however, a significant difference among the observations of heads and members about their selection from community representatives $(\mathrm{t}=2.46, \mathrm{p}<0.05)$. Head teachers negate that members were attending meetings regularly $(\mathrm{t}=4.68, \mathrm{p}<0.05)$; heads reported that members were found passive $(\mathrm{mean}=1.45)$; There was a significant difference among the observation of heads and members of SMC regarding the process of discussion about management $(\mathrm{t}=4.73, \mathrm{p}<0.05)$. In this way, members of SMCs reported that proper discussion about school management was held, whereas heads reported that such type of discussions were ignored by members. Members also reported that hindrance was produced in administrative decisions $(t=2.87, \mathrm{p}<0.05)$.

Table 2 indicates that both head teachers and members of SMCs have similar type perceptions about performance and indicates that SMCs have performed their role for promotion of education, making changes in a general nature, and improvements in results. It might be observed that head teachers and members were having similar observations in various aspects of amelioration of educational conditions associated with performance of SMCs, especially making feasible plans; implementing these plans; and improvements of staff attendance through SMCs were reported ineffective by head teachers. Definitely there are such aspects which are assumed to be handled directly by heads and some type of involvement in such matters may produce lack of direct control by administrators, especially when there is an autocratic type of administration. 
Table 2: Performance of School Management Committees

\begin{tabular}{|l|c|c|c|c|c|}
\hline \multicolumn{1}{|c|}{ Items } & \multicolumn{2}{c|}{ Head teacher } & \multicolumn{2}{c|}{ Members } & \multirow{2}{*}{ t value } \\
\cline { 2 - 5 } & Mean & SD & Mean & SD & \\
\hline Promotion of education & 3.31 & 0.90 & 3.25 & 1.03 & 0.34 \\
\hline Changes of general nature & 2.71 & 1.09 & 2.77 & 1.20 & 0.35 \\
\hline Feasible plans & 1.67 & 1.28 & 2.2 & 1.56 & $2.29^{*}$ \\
\hline Implementation of these plans & 1.39 & 1.09 & 2.86 & 1.21 & $7.87^{*}$ \\
\hline Improvement of staff's attendance & 2.76 & 1.13 & 3.13 & 1.02 & $2.13^{*}$ \\
\hline Acceleration of admission rate & 3.13 & 1.09 & 1.87 & 1.42 & $6.13^{*}$ \\
\hline Abatement of drop out rate & 2.97 & 1.09 & 2.2 & 1.41 & $3.75^{*}$ \\
\hline Improvement of teaching learning process & 2.71 & 1.09 & 2.26 & 1.50 & $2.06^{*}$ \\
\hline Satisfaction of staff with SMC & 2.8 & 1.27 & 2.05 & 1.15 & $3.70^{*}$ \\
\hline Improvements of results & 2.65 & 1.18 & 2.56 & 1.12 & 0.50 \\
\hline
\end{tabular}

Corresponding $\mathrm{t}=1.96$ with $\mathrm{df}=148$, at 0.05 level.

\section{CONCLUSIONS AND DISCUSSION}

SMC members were selected under the supervision of authorities. Head teachers commented that SMC members represented the community while, according to members, the representation of community in SMCs was partial; so they desired to enhance the span of community representation. SMC members commented that meetings were held regularly, while head teachers had reservations about scheduling the meetings regularly on the part of members. This shows the head teachers' demand for SMC members to show their regularity in meetings. The majority of head teachers and SMC members commented that they were not active. Most of the head teachers commented that they fully maintained the proceedings, while to SMC members, proceedings were not maintained properly. Head teachers cooperated with SMC members to some extent. Decision-making enables administrators to make more rational decisions among conflict, uncertainty and unfavorable circumstances (Anwar et. al., 2008). To SMC members, school management has improved much, while head teachers indicated that improvement in school management was not up to mark. Members reported that hindrance was produced in administrative decisions, whereas heads had no such feelings. Per members, the hindrance may stand for their involvement and effect upon the decision-making process, whereas heads may take it as part of the decision-making process to have some common consensus.

SMC members indicated that school discipline improved with involvement of SMCs, while head teachers negated it. Most head teachers indicated that SMCs created problems to some extent, while SMC members disagreed with the statement. The majority of head teachers and SMC members agreed that education was improved by SMCs. The majority of head teachers and SMC members agreed that attendance of staff had been improved after the establishment of SMCs, while officers had no opinion. The majority of head teachers agreed that admission rate had been accelerated by SMCs, while SMC members had no opinion. Most head teachers indicated that SMCs decreased the dropout rate, while SMC members had no opinion. Head teachers agreed that the teaching-learning process had been improved by SMCs, but SMC members were found uncertain in this regard. The majority of head teachers agreed that staff was satisfied with the functioning of SMCs, while the officers and SMC members had no opinion about the statement. The majority of head teachers and SMC members agreed that school results had been improved. The majority of head teachers and SMC members had no opinion about cooperation of SMCs in the fund-generating campaign.

Admittedly, for amelioration of educational conditions in schools, along with the performance of SMCs, some other measures - like better morale of, enriched curriculum, school community collaboration, and controlled class size - should also be considered. It is therefore recommended to prepare a criterion for fixing a minimum qualification for SMC members being selected and for continued monitoring and strong coordination among government functionaries and SMCs. In the implementation process, the innovative administrative aspects must be kept forth and SMCs should be involved in decision-making and implementation of policies. SMCs should be informed of the allocations made for the promotion of education in their schools so that they know how the resources allocated for the development of their schools are actually spent; and there should be effective decentralization of administrative and financial powers to the SMCs. 


\section{AUTHOR INFORMATION}

Muhammad Imran Yousuf is working as Assistant Professor in Division of Continuing Education, Pir Mehr Ali Shah Arid Agriculture University, Rawalpindi, Pakistan.. He did his M.Phil. in Teacher Education from Allama Iqbal Open University, Pakistan and Ph.D. in Education from University Institute of Education and Research, UAAR, Pakistan. E-mail: dr.imran@uaar.edu.pk

Muhammad Tayyab Alam is working as Associate Professor in Foundation University, Rawalpindi, Pakistan.. He did his M.Phil. in Teacher Education from Allama Iqbal Open University, Pakistan and Ph.D. in Education from University Institute of Education and Research, UAAR, Pakistan. E-mail: mta69@yahoo.com

Muhammad Latif Sajjad is working as senior Secondary School teacher in Govt. of Punjab School Wing.. He did his M.Phil. in Teacher Education from Allama Iqbal Open University, Pakistan. E-mail: mlatiffsajjad@yahoo.com

Muhammad Imran has completed Ph.D. in Education from University Institute of Education and Research, UAAR, Pakistan. E-mail: mimranniaziuier@yahoo.com

\section{REFERENCES}

1. Ahmed, M. (1997), Planning, Management and Administration of Basic Education: Case Studies on Innovations in Basic Education in Pakistan. Islamabad: Primary, Non-Formal Education and Curriculum Wing Ministry of Education.

2. Anwar, M.N., Yousuf, M.I., Sarwar, M. (2008) Decision Making Practices in Universities of Pakistan. Journal of Diversity Management. 3(4); 19-26.

3. Cheung, S.M.C., Kan, F.L.F. (2009) Teachers' perceptions of Incorporated Management Committees as a form of school-based management in Hong Kong. Asia Pacific Education Review. 10:139-148.

4. Farooq, R.A. (1994), Education System in Pakistan, Issues and Problems, Islamabad: ASPIRE.

5. Government of Pakistan (1998), National Education Policy 19998-2010, Islamabad: Ministry of Education.

6. Jamil, B. (1996) Education in Urban Slum Areas of Pakistan: Experiences of the Faisalabad Area Upgrading Project, Faisalabad: FAUP.

7. Khan, S.R. (2000) Educating the Educators: Power Devolution and Community Participation in Basic Education: The News, April 23, 2000.

8. Sarwar, G. (1984) Syllabus and Guidelines for Islamic Teaching, London: The Muslim Educational Trust.

9. Sarwar, M., Yousuf, M.I., Hussain, S. (2010) Attitude towards Democracy in Pakistan: Secondary School Teachers' Perceptions. Journal of College Teaching \& Learning. 7(3): 33-37

10. Shahid, S.M. (1998), Public Administration: Theory \& Practice in Pakistan, Lahore: Publishers Emporium.

11. UNESCO (1997), Educational Innovation for Sustainable Development Bangkok: UNESCO, Principal Regional Office for Asia and the Pacific.

12. Yousuf, M.I., Sarwar, M., Darth, G., Naseer-ud-Din, M. (2010) Peace perceptions of prospective teachers for promoting peace activities for school setting in Pakistan. Journal of College Teaching \& Learning. 7(3): 53-58. 
NOTES 